The University of Maine

\title{
DigitalCommons@UMaine
}

Sociology School Faculty Scholarship

Sociology

2013

\section{Harassment of Older Adults in the Workplace}

Amy Blackstone

University of Maine, Orono, amy.blackstone@maine.edu

Follow this and additional works at: https://digitalcommons.library.umaine.edu/soc_facpub

Part of the Gerontology Commons, Social Psychology and Interaction Commons, Sociology of Culture Commons, and the Work, Economy and Organizations Commons

\section{Repository Citation}

Blackstone, Amy, "Harassment of Older Adults in the Workplace" (2013). Sociology School Faculty Scholarship. 6.

https://digitalcommons.library.umaine.edu/soc_facpub/6

This Book Chapter is brought to you for free and open access by DigitalCommons@UMaine. It has been accepted for inclusion in Sociology School Faculty Scholarship by an authorized administrator of DigitalCommons@UMaine. For more information, please contact um.library.technical.services@maine.edu. 


\section{Metadata of the chapter that will be visualized online}

\begin{tabular}{|c|c|c|}
\hline \multicolumn{3}{|l|}{ Series Title } \\
\hline Chapter Title & \multicolumn{2}{|c|}{ Harassment of Older Adults in the Workplace } \\
\hline \multicolumn{3}{|l|}{ Chapter SubTitle } \\
\hline Copyright Year & \multicolumn{2}{|l|}{2013} \\
\hline Copyright Holder & \multicolumn{2}{|c|}{ Springer Science + Business Media Dordrecht. } \\
\hline \multirow[t]{8}{*}{ Corresponding Author } & Family Name & Blackstone \\
\hline & Particle & \\
\hline & Given Name & Amy \\
\hline & Suffix & \\
\hline & Division & Department of Sociology \\
\hline & Organization & University of Maine \\
\hline & Address & 5728 Fernald Hall, 04469, Orono, Maine \\
\hline & Email & Amy.blackstone@umit.maine.edu \\
\hline Abstract & \multicolumn{2}{|c|}{$\begin{array}{l}\text { This chapter reviews research on harassment of older adults in the workplace and highlights results from } \\
\text { my recent study of harassment of older workers in Maine. I suggest that the power that older people hold } \\
\text { at work, at home, and in their communities shapes their workplace harassment experiences. Based on a } \\
\text { survey of nearly } 200 \text { Maine workers aged } 62 \text { and above, four questions framed the study: (1) What is the } \\
\text { contentof older workers' harassment experiences?; (2) Which older workers are most likely to become } \\
\text { targetsof workplace harassment?; (3) How do older workers respondto potentially harassing behaviors?; } \\
\text { and (4) What do older workers have to say about their workplace experiences? I find that workplace } \\
\text { isolation is one of the most common harassment experiences among older workers, that gender differences } \\
\text { are less prominent than anticipated, and that many older workers remain silent about their harassment } \\
\text { experiences. I conclude by considering what these findings suggest about improving older people's } \\
\text { workplace experiences. }\end{array}$} \\
\hline
\end{tabular}




\title{
Chapter 3 \\ Harassment of Older Adults in the Workplace
}

\author{
Amy Blackstone
}

How do workers come to define certain experiences as workplace harassment and how do they respond to such experiences? How do age, gender, and power across domains such as work, family, and community life shape victimization experiences and mobilization, or actions, in response to harassment? Over time, scholars in diverse specializations such as work, aging, law, gender, and criminology have addressed these and similar questions. In this chapter, I combine these diverse perspectives in order to assess how age, gender, and other dimensions of power shape older workers' harassment experiences.

It is estimated that by the year 2012, approximately $20.8 \%$ of men and $12.1 \%$ of women aged 65 and over will be participating in the U.S. labor force, up from $16.3 \%$ of men and $8.6 \%$ of women in 1990 (U.S. Bureau of the Census 2006, p. 387). The projected increase in labor force participation among older workers is explained by the aging of the baby boomer generation. Not only are baby boomers getting closer to traditional retirement age, they also appear likely to continue their labor force participation longer than their predecessors did. Although labor force activity declines after age 62 (National Institute on Aging NIA 2007), a recent survey by the

\footnotetext{
An earlier version of this chapter was presented at the 2010 meeting of the American Sociological Association. Direct correspondence to amy.blackstone@umit.maine.edu. This research was supported by a grant from the National Science Foundation (SES-0817673). Many thanks to Mahala Stewart and Michael J. Costello for research assistance.
}
A. Blackstone, Ph.D. ( $\square)$
Department of Sociology, University of Maine,
5728 Fernald Hall, Orono, Maine 04469
e-mail: Amy.blackstone@umit.maine.edu 


\section{Author's Proof}

American Association of Retired Persons (AARP 2004) found that 8 out of 10 baby boomers expected that they would continue working, at least part time, after they reached the age of initial eligibility for Social Security benefits.

As the nation confronts an aging workforce, so too does it face an increasingly broader class of workers for whom the United States Equal Employment Opportunity Commission (EEOC) provides the right to protections (Wakefield and Uggen 2004). In 2004 the EEOC reported having received 17,837 complaints filed under the Age Discrimination in Employment Act (U.S. EEOC 2006). The number of age-based complaints rivaled the number of charges filed under the Americans with Disabilities Act $(15,376$ in 2004) and was not far behind the more common categories of sex- and race-based complaints (24,249 and 27,696 in 2004, respectively). These statistics matter for any study of power in the workplace because, as two prominent scholars of aging recently put it, "Old people lose authority and autonomy" (Calasanti and Slevin 2006, p. 6).

Such estimates and projections have prompted public, political, and scholarly discussion of the unique health and safety issues facing aging workers and their employers (e.g., National Institute for Occupational Safety and Health 2004) and also the potential benefits of an aging workforce (e.g., Nacelewicz 2005; Sterns and Miklos 1995). Much research in the area focuses on employers' and coworkers' attitudes toward older workers and the impact of an aging workforce on the structure of the workplace (e.g., Brooke and Taylor 2005; Duncan 2003; Marshall 2001; Pitt-Catsouphes 2005; Rix 2001; Siegenthaler and Brenner 2000; Sterns et al. 1994; Taylor and Walker 1998); access to employment (e.g., Bendick et al. 1999; Hirsch et al. 2000); and workers' plans for retirement and reasons for later-life labor force participation (Appold 2004; Eichar et al. 1991; Ekerdt et al. 2000; Singh and Verma 2003). Other research studies focus on ageism but not on workplace sexual harassment or bullying per se (Dennis and Thomas 2007; Macnicol 2006; McMullin and Marshall 2001).

All these areas of inquiry are important. Yet so too is consideration of workers' own perceptions of their experiences. Although some scholars have studied older workers' perceptions of workplace discrimination (e.g., Altschuler 2004; Mor-Barak 1995; Tougas et al. 2004), these scholars have not considered the broader theoretical implications of their findings. In an AARP study of persons aged 55 and above, some participants wished to work but were not seeking employment because they feared they would be perceived as "too old" by employers, or face other forms of discrimination. The researchers concluded that "age continues to work against many older jobseekers" (Rix 2005, p. 3).

A number of questions remain unanswered. How does age impact workers' vulnerability to harassment and discrimination? What are workers' perceptions of their own vulnerability? And how do these perceptions change for workers as they gain experience in the labor force?

Insights from several areas of inquiry framed this study. Much knowledge has been gained about power in the workplace thanks to the efforts of feminist and gender scholars. Scholars of aging provide important additional insight into the experiences and perspectives of older individuals. Knowledge about workplace 


\section{Author's Proof}

3 Harassment of Older Adults in the Workplace

violence and victimization comes from scholars in the field of criminology, while understandings of legal consciousness and mobilization in response to harassment have been informed by socio-legal studies. Below I describe insights from these areas of inquiry with particular attention to how each area applies to the present study of harassment of older workers. In addition to the areas already mentioned, I also consider insights from life course studies and the sociology of work.

\section{Power in the Workplace: Diverse Perspectives}

Age, gender, social class, and access to social networks and support are among the most salient determinants of power shaping workplace interactions and experiences (see, e.g., Acker 1990; Calasanti and Slevin 2001, 2006; Kanter 1977; Rospenda et al. 1998; Uggen and Blackstone 2004). In the following section I draw from diverse perspectives to describe the dynamics of power relations and harassment in the workplace.

Within the scholarly community, gender researchers were among the first to draw attention to issues of power in the workplace. As the feminist movement of the 1960s and 1970s took shape, activists and scholars brought into public view what many knew privately, but did not discuss: some workplaces were fraught with problematic sexualized interactions shaped by a hegemonic gender ideology in which men asserted and maintained sexual and other dominance over women colleagues. These kinds of workplace interactions were labeled sexual harassment. Catherine MacKinnon's 1979 book, Sexual Harassment of Working Women, helped push the issue further into public view and placed it on the political and legal agenda. Sociocultural work in this area highlighted gender-based power differentials as the primary predictor of sexual harassment victimization (Welsh 1999). Although the research findings I present in the following sections of this paper are not limited to sexual harassment only, the insights of studies confined to sexual harassment should not be overlooked. This large and diverse body of literature offers general insight into power dynamics in the workplace, in part because the focus of much sexual harassment research has broadened over the years.

Sexual harassment researchers initially focused on gendered dimensions of power in the workplace, but the literature has since grown to include inquiry into the relationships between and among intersecting dimensions of power. For example, Rospenda et al. (1998) drew attention to the multiple levels at which power plays out in the workplace, arguing that the effects of gender, race, and class operate simultaneously, at cultural, organizational, and individual levels to shape individuals' workplace experiences. Additional research supports the idea that together gender, race, and class shape workplace harassment experiences (Giuffre and Williams 1994; Texeira 2002) as does sexual identity (DeSouza and Solberg 2004) and citizenship status (Welsh et al. 2006). Increasingly, sexual harassment researchers are including consideration of age as an additional dimension of power shaping workplace experiences. 


\section{Author's Proof}

The literature on age and work has a long history (e.g., Brooke and Taylor 2005; Marshall et al. 2001; Mortimer 2003) but within the context of workplace harassment, age has typically been left out of consideration. Studies of workplace sexual harassment that do analyze the impact of age on experiences or perceptions focus almost exclusively on mid-life or younger workers (Fineran 2002; Ford and Donis 1996; Padavic and Orcutt 1997; Uggen and Blackstone 2004) or rely on hypothetical scenarios rather than actual experiences (Wayne 2000). Other studies, focusing more generally on age as a dimension of power, examine its impact within various domains of social life, but not necessarily within the context of paid employment (e.g., Hess 1990; Levy 1988). Broader treatments of the impact of work on older adults have been published (e.g., Schaie and Schooler 1998) but have been criticized for not fully integrating the interaction of age with additional power dimensions such as race, class, and gender (Calasanti 1999).

A growing literature considers how age intersects with other power dimensions to influence work experiences and patterns (e.g., Barnett 2005; Calasanti 2002; Calasanti and Slevin 2001, 2006; McMullin and Marshall 2001; Smith and Calasanti 2005). Dominant conceptualizations of work itself highlight the connections between age and other dimensions of power. As Calasanti and Slevin (2001) noted, "productivity" should not be equated with paid labor alone, and older volunteers and others who participate in informal economies make this clear. Despite these advances in the conceptualization of age and power, Allen and Walker (2006), in an article on the importance of studying age, claimed that, "Much more integration is needed to connect a gender lens and an aging lens across disciplines..." (p. 155). McMullin (2000) suggested that age relations typically have not been considered in the social inequality literature alongside other dimensions of power such as gender, race, class, and sexual orientation. (See also King 2006). Finally, McMullin and Berger (2006) concluded that "relative to sexism, very little is known about the mechanisms through which ageism is manifested in paid work environments" (p. 219).

In addition to considering the literature on gender, it is also important to integrate the aging literature with insights from other disciplines, including criminology and law. Bringing criminological insights together with those from the study of gender, De Coster and her colleagues (1999) were among the first to test how well a general theory of victimization explains sexual harassment, applying routine activities theory to show that workplace victimization can be attributed to the presence of motivated offenders, the proximity of vulnerable targets, and the absence of solidaristic, or cohesive, work groups. Routine activities and other criminological theories focusing on motivated offenders and organizational culture point to the importance of analyzing the relationships between individual-level characteristics and the structural and institutional contexts within which individuals operate (Cohen and Felson 1979; De Coster et al. 1999; Knefel et al. 2004; Mueller et al. 2001). These theories are therefore useful for examining the role that age plays in shaping workers' experiences.

Researchers in this area also have described the dynamics and features of workplace violence and harassment. Building from their own and others' work on harassment and generalized workplace abuse (Fendrich et al. 2002; Richman et al. 1999; Rospenda 2002; Rospenda, et al. 2000), Rospenda and Richman (2004) developed a typology 


\section{Author's Proof}

3 Harassment of Older Adults in the Workplace

of generalized workplace harassment which includes covert hostility, verbal hostility, manipulation, and physical hostility. Others have studied "workplace abuse," expounding upon bullying and mobbing, two of the more dominant forms of abuse (e.g., Koonin and Green 2004).

In addition to these areas of inquiry, the present study also drew from the socio-legal perspective, which provides insight into individuals' perceptions of, and responses to, harassment. Theories of legal consciousness point to cultural and social-psychological factors in shaping perceptions of justice and responses to perceived injustices (Bumiller 1988; Ewick and Silbey 1998; Felstiner et al. 1980-81; Kritzer et al. 1991; Merry 1990). According to these theories, cultural schema, as well as social resources, shape individuals' understandings of law and legality.

Ewick and Silbey (1998) suggested that legal consciousness can take several different forms. One form causes individuals to perceive the law and legality as all-powerful and impenetrable, something over which they have little control. Others might believe that law and legality are a series of meaningless rules and therefore something to be manipulated. Finally, some view the law as a power to be avoided or resisted (see also Ewick and Silbey 2003). The concept of legal consciousness allows for the expression and examination of legality in ways not officially recognized by the law. Although it may be typical to think of the law as being enacted in formal, traditional ways (e.g., through lawsuits), law can also be invoked in informal, less official ways. A growing body of literature addresses various forms of legal consciousness and the contexts within which it is manifested (e.g., Connolly 2002; Fleury-Steiner 2003; Hoffman 2005; Hull 2003; Marshall 2005; Marshall and Barclay 2003; Richman 2001). However, the question of how or whether legal consciousness varies by age has not yet been examined.

Not only can legal consciousness take a variety of forms, but the invocation of the law and legality occurs in different ways (Hoffman 2003). Further, because research on aging populations shows that many are reluctant to acknowledge the impact or existence of ageism in their own lives or to self-identify as "old" (e.g., Fairhurst 2003; Minichiello et al. 2000), it is possible that older workers will not choose to identify their experiences either as harassment or as having anything to do with their age. Thus, mobilization in response to harassment, and as shaped by legal consciousness, may work differently for differently positioned workers. For example, workers with more resources to draw from, such as positive coworker, friend, or family relationships, may respond differently to harassment than those with fewer sources of social support. I consider these and other predictions in the form of "objectives questions" below.

\section{Objectives Questions}

This study is framed by four objectives, each presented in the form of a question. The study rests on the assumption that workers in the United States operate within a culture where particular dimensions of power, such as age and gender, are especially salient; youth is valued over age (Levy 1988); and hetero-normative masculinity is 
placed hierarchically above all other expressions of gender (Blackstone 2003). In the workplace especially, "old people face repudiation from younger people as being weak, sick, and unable to learn and as nearing death" (King 2006, p. 54). Within this context, workers hold variable amounts of power across several domains including the workplace, family life, and community life. In the present study I addressed the following questions about older workers' harassment experiences:

1) What is the content of older workers' harassment experiences?

2) Which older workers are most likely to become targets of workplace harassment?

3) How do older workers respond to potentially harassing behaviors?

4) What do older workers themselves have to say about their workplace experiences?

\section{Data and Measures}

The data come from a sample of workers identified with the assistance of one statelevel division of a national program designed to place older workers by providing training and matching older workers with potential employers. This division serves approximately 380 clients each year and tracks and maintains contact information for past clients. Surveys were sent to 576 eligible past and current program participants who had been in the paid workforce at some point since turning age 62 . Of these 576 individuals, 183 workers completed the survey, yielding a response rate of $32 \%$. Although a variety of techniques were used to ensure a high response rate, ${ }^{1}$ it is possible that one lesson to come from this research is that mailed questionnaires are not the most effective method of data collection for an older population, particularly when participants are asked to share details about workplace experiences that they may fear put them at risk of losing needed employment.

The age range of those who returned the survey was 62-87 years old; the mean age of participants was 70 years old and the media age was 68.5 years old. Seventy-six per cent of participants were women and $96 \%$ were white. The gender and race composition of participants reflected that of all program participants in the state where data were collected. Thirty-one per cent of participants had graduated from high school, $30 \%$ had completed some college, and $8 \%$ had earned a bachelor's degree.

\footnotetext{
${ }^{1}$ All potential participants were notified in advance of the survey mailing via an article describing the research and the planned mailing in the program's monthly newsletter. A $\$ 1$ bill was included with each survey in the initial mailing to provide an incentive and an advance token of thanks to participants for returning the surveys. Two months after the initial mailing went out, those who were sent a survey were contacted by phone. Although returned surveys did not contain any identifying information about participants, research assistants contacted individuals to whom a survey had been mailed to remind them that it was not too late to return their survey and to say thanks to those who had already done so. Four months after the initial mailing, everyone on the original mailing list received a letter thanking those who had returned the survey and once again reminding those who had not, that it was not too late to do so. The letter included a return postcard for participants to complete should they wish to receive another copy of the survey. Participants were also provided a telephone number to call and the option of completing the survey by phone.
} 


\section{Author's Proof}

3 Harassment of Older Adults in the Workplace

The primary focus of the survey was a set of workplace harassment questions, based on indicators used in other researchers' studies of generalized harassment (Koonin and Green 2004; Rospenda and Richman 2004) as well as indicators used in my own prior research on workplace harassment (McLaughlin et al. 2008; Uggen and Blackstone 2004). Additional questions, including who participants notified about harassment (e.g., no one, friends, family, coworkers, supervisors, attorneys, or government authorities) were placed on the survey, as was demographic and other background information. I also collected data on other aspects of participants' lives such as closeness in their relationships with family and friends. In addition to the quantitative survey questions, two open-ended questions were included on the survey in which participants were asked whether they believed any of their harassment experiences had anything to do with their age or gender (and to explain if so). A final open-ended question asked participants to describe what they had most enjoyed about their work experiences since turning 62 .

\section{Results}

\section{Objective 1: What Is the Content of Older Workers' Harassment Experiences?}

Table 3.1 presents participants' reports of their harassment experiences.

As shown in Table 3.1, the four most common behaviors that participants said they encountered at work were having their work contributions ignored $(25.1 \%)$; being left out of decisions that affect their work (23.0\%); being talked down to by coworkers (20.8\%); and being talked down to by bosses $(20.2 \%)$. All four of these experiences indicated older workers' sense of being devalued in the workplace.

In my prior collaborative research on younger workers (Uggen and Blackstone 2004), my co-investigator and I asked about behaviors similar to those included in the present older worker survey. There were notable differences in the reports of younger and older workers. For example, younger workers most commonly experienced various kinds of offensive joking. Also, experiencing unwanted staring or invasion of personal space was much more common among younger workers. In both the younger and older worker samples, sexual assault and unwanted touching were rare, but both experiences were even less common among older workers. These patterns suggest that even though workers of all ages may be vulnerable to harassment, younger and older workers differ in the types of harassment they experience. The ways that workplace harassment manifests itself may change as workers age.

Additional behaviors that at least $10 \%$ of participants reported included verbal exchanges characterized by yelling or swearing; offensive age-related joking about the participant; offensive age-related joking about others; offensive sexual joking about others; being isolated from important work activities; comments or behaviors that demeaned participants' age; and unwanted questions about participants' private lives. 


\section{Author's Proof}

t1.1 Table 3.1 Percent of older workers who experienced various types of harassing behaviors ${ }^{\mathrm{a}}$

\begin{tabular}{|c|c|c|}
\hline $\mathrm{t} 1.2$ & At any job you have held since turning 62, have you experienced... & $\%$ Yes \\
\hline $\mathrm{t} 1.3$ & ...Verbal exchanges characterized by yelling or swearing & $13.1 \%$ \\
\hline $\mathrm{t} 1.4$ & ...Being talked down to by coworkers & 20.8 \\
\hline $\mathrm{t} 1.5$ & ... Being talked down to by customers & 8.2 \\
\hline $\mathrm{t} 1.6$ & ...Being talked down to by bosses & 20.2 \\
\hline $\mathrm{t} 1.7$ & ...Offensive age-related joking about you & 9.8 \\
\hline $\mathrm{t} 1.8$ & ...Offensive age-related joking about others & 11.5 \\
\hline $\mathrm{t} 1.9$ & ...Offensive sexual joking about you & 2.7 \\
\hline $\mathrm{t} 1.10$ & ...Offensive sexual joking about others & 10.4 \\
\hline $\mathrm{t} 1.11$ & ...Having your work contributions ignored & 25.1 \\
\hline $\mathrm{t} 1.12$ & ...Subtle or obvious threats to your safety & 3.3 \\
\hline $\mathrm{t} 1.13$ & ...Bribes to do things that are wrong & 1.6 \\
\hline $\mathrm{t} 1.14$ & ...Being hit, pushed or grabbed & 2.7 \\
\hline $\mathrm{t} 1.15$ & ...Being isolated from important work activities & 12.6 \\
\hline $\mathrm{t} 1.16$ & ...Being left out of decisions that affect your work & 23.0 \\
\hline $\mathrm{t} 1.17$ & ...Comments or behaviors that demean your gender & 5.5 \\
\hline $\mathrm{t} 1.18$ & ...Comments or behaviors that demean your age & 12.6 \\
\hline $\mathrm{t} 1.19$ & ...Unwanted questions about your private life & 10.4 \\
\hline $\mathrm{t} 1.20$ & ...Staring or invasion of your personal space & 7.7 \\
\hline $\mathrm{t} 1.21$ & ...Unwanted touching & 1.6 \\
\hline $\mathrm{t} 1.22$ & ...Sexually explicit pictures, posters, or other materials & 1.1 \\
\hline $\mathrm{t} 1.23$ & ...Sexual assault by a coworker or boss & 1.1 \\
\hline
\end{tabular}

\section{Objective 2: Which Older Workers Are Most Likely to Become Targets of Workplace Harassment?}

To understand which older workers were most likely to become targets of workplace harassment, I conducted $t$-tests of differences in responses to the harassment indicators between the following categories of participants: women and men; those who had close family relationships and those who did not; and those who had close friend relationships and those who did not. I compared responses on these measures for the objective, or behavioral, harassment indicators that at least $10 \%$ of respondents reported experiencing as well as participants' own perceptions of whether their experiences qualified as harassment. Table 3.2 presents results from $t$-tests of differences on the objective harassment indicators and on participants' perceptions of whether experiences qualified as various forms of harassment.

Tests for gender differences reveal that there were no statistically significant differences between men and women in their responses to the objective harassment indicators. There were also no significant differences between men's and women's perceptions of their experiences.

In the survey, participants were asked whether they would define any of their experiences as bullying, hostile, harassment, or sexual harassment. Based on findings in my prior research on younger workers (Uggen and Blackstone 2004), I hypothesized 


\section{Author's Proof}

3 Harassment of Older Adults in the Workplace

that men would be significantly less likely than women to define their experiences as harassment. Cultural realities, as well as stereotypes about gender, prescribe that women are more likely than men to be victimized. Men are also less likely than women to be socialized to think of themselves as potential victims and I therefore hypothesized that they would be less likely to perceive that they had been harassed. The finding in the present study that men and women did not differ in the likelihood of perceiving that they had been targets of workplace harassment suggests that the salience of gender as a part of workers' identities may differ based on a worker's age. Indeed, prior research on gender and aging processes generally (e.g., Meadows and Davidson 2006) and older workers specifically (e.g., McMullin and Berger 2006) suggested that older individuals may experience bullying or hostility from coworkers due to their age more than their gender.

The $t$-test results suggest that closeness with family and friends had some impact on harassment experiences but almost no impact on perceptions of workplace harassment experiences. Predictions from routine activities theory suggest that close family and friend relationships may serve a protective function; those with close ties may be perceived by harassers to be less vulnerable targets as they are more likely to have the resources to report and respond to harassment. Conversely, those with close ties might be more likely to perceive harassment as individuals with whom participants have close relationships can serve as "sounding boards" for participants, enabling them to examine their workplace experiences more critically than they might without others with whom to discuss them.

In terms of behavioral experiences, those who reported having close relationships with family were less likely than those lacking close family relationships to report being talked down to by bosses, less likely to report having their work contributions ignored, and less likely to report being isolated from important work activities. Those who reported having close relationships with friends were less likely than those lacking close friend relationships to report being isolated from important work activities and less likely to report experiencing unwanted questions about their private lives.

While closeness with family had no effect on perceptions of any kind of harassment, closeness with friends was significantly related to perceptions of sexual harassment. As shown in Table 3.2, those who had close friends were more likely than those who did not to perceive their experiences as sexual harassment. Of course, one should take into account that the findings reported in Table 3.2 are rather weak given the number of $t$-tests run.

\section{Objective 3: How Do Older Workers Respond to Potentially Harassing Behaviors?}

Table 3.3 presents findings from the questions asking older workers to whom they 


\section{Author's Proof}

A. Blackstone

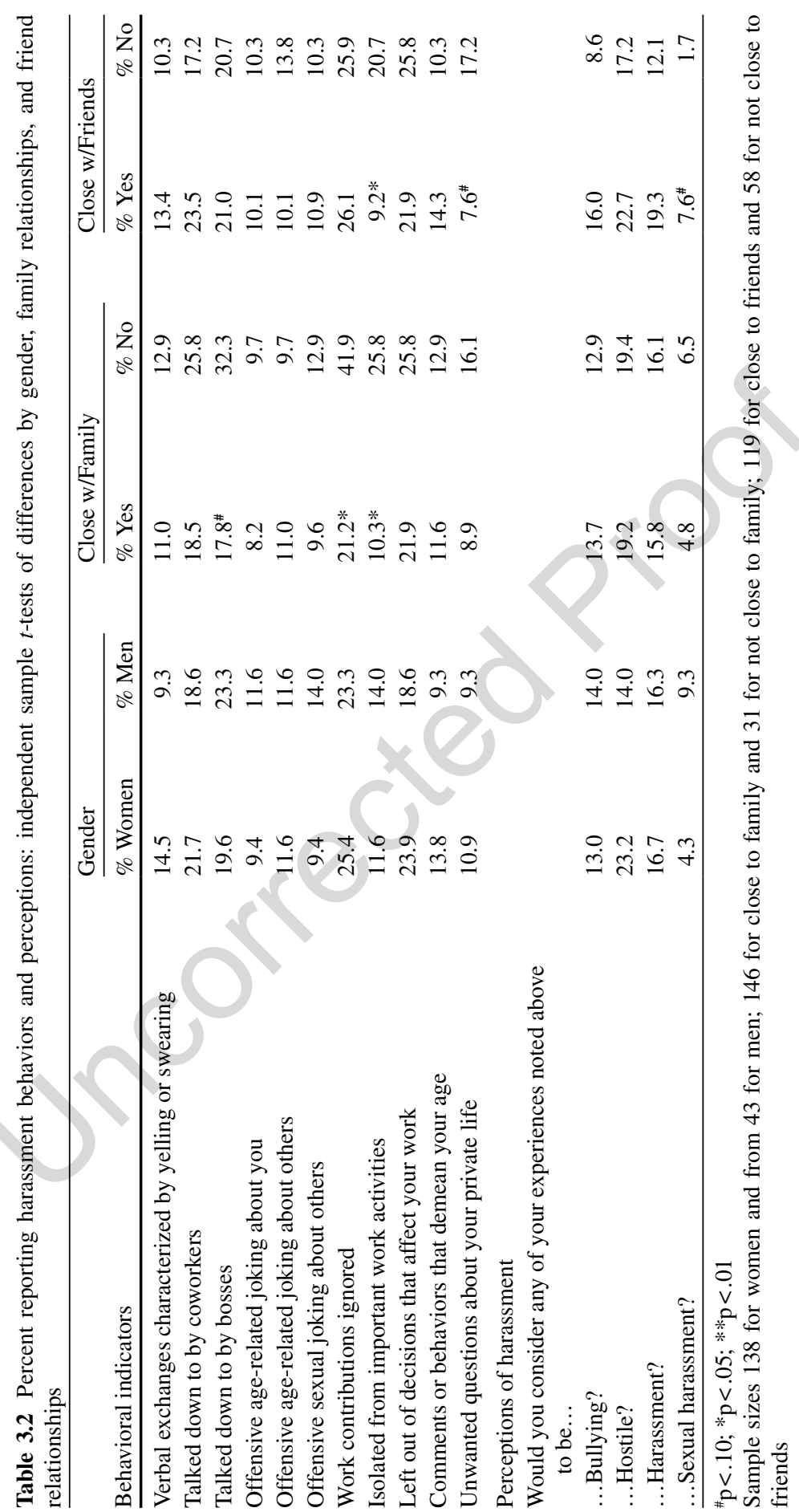




\section{Author's Proof}

3 Harassment of Older Adults in the Workplace

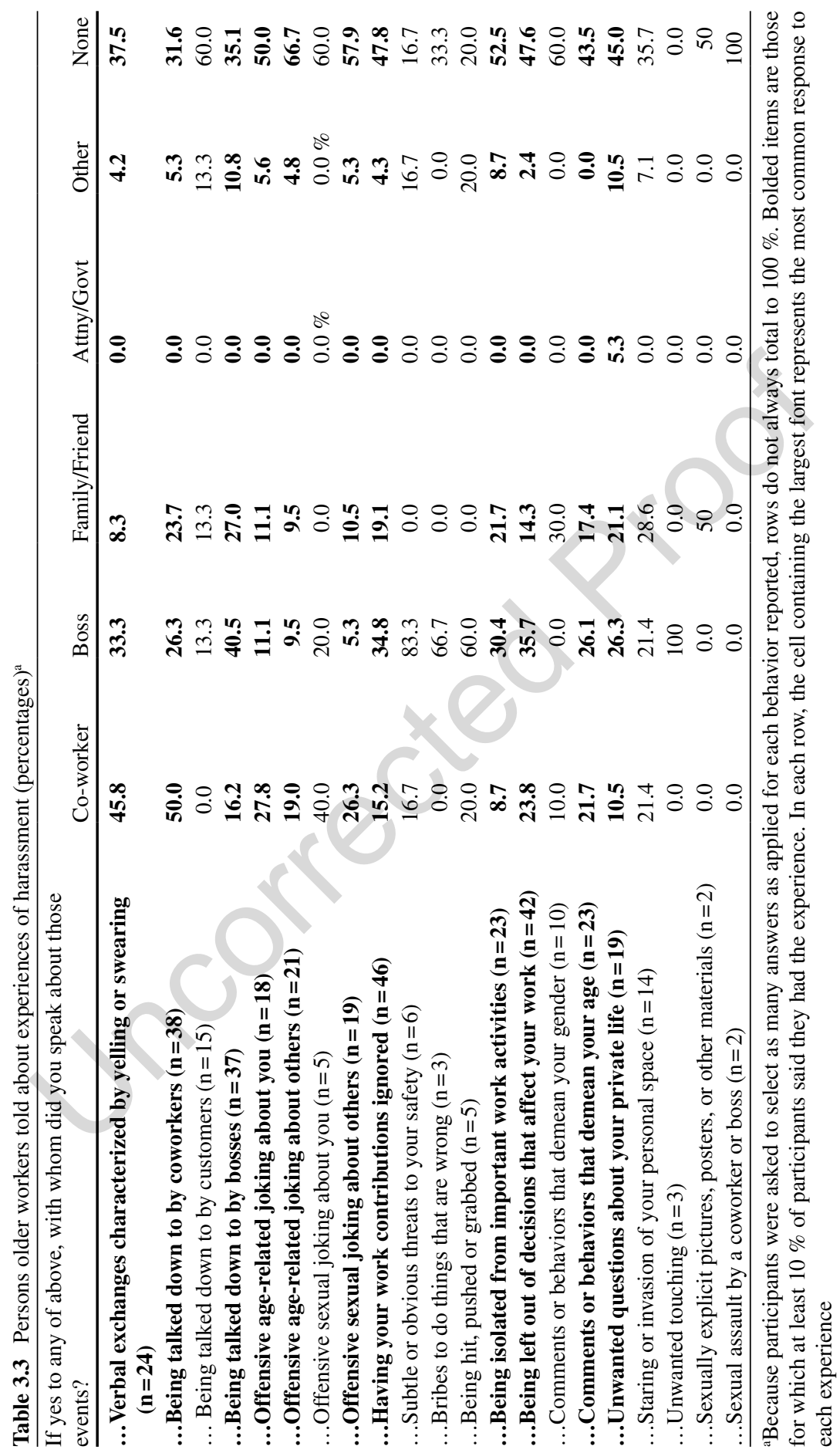


Twenty-four participants experienced verbal exchanges characterized by yelling or swearing. Of these, $45.8 \%$ told a coworker; $33.3 \%$ told a boss; $8.3 \%$ told a family member or friend; $4.2 \%$ told someone other than those specifically asked about on the survey; and $37.5 \%$ told no one.

Overall, there are several notable patterns in Table 3.3. First, only one participant told an attorney or government agency about any experience. The single instance in which a participant told an attorney or government agency about his/her experience was in response to unwanted questions about his/her private life. Second, participants were likely to confront their harassers directly: the largest "who told" cell in the "talked down to by coworkers" row is coworkers and the largest "who told" cell in the "talked down to by bosses" is bosses. However, many participants told no one about their experiences of harassment.

\section{Objective 4: What Do Older Workers Themselves Have to Say About Their Workplace Experiences?}

As noted, I included three open-ended questions on the survey, asking participants whether they believed any of their harassment experiences had anything to do with their age or gender (and, if so, to explain) and to describe what they have most enjoyed about their work experiences since turning 62 . In addition, many participants wrote unsolicited comments in the margins of the survey. While a small number of participants reported that their gender or age had something to do with their harassment experiences, far more participants wrote in the margins of their surveys, describing reasons for continuing work at their age. Most common reasons cited for working included financial need, maintaining social connections, and remaining mentally, physically, and/or emotionally functional.

Participants who added written remarks to the survey more typically wrote about positive, rather than negative, workplace experiences. Those who reported positive experiences said that working helped them maintain their independence; gave them a chance to socialize; provided them an opportunity both to learn and to share their knowledge; kept them busy; and made them feel useful and helpful. For example, one woman wrote, "I take pleasure to be with people. I love working. It keeps your mind alive, your body moving. I have a reason to get up in the morning." Another said, "My co-workers are fun to work with and I enjoy being able to earn some very much needed and appreciated money. I also appreciate the opportunity to learn new things." One woman wrote that she most enjoys, "Pride in my work, sense of accomplishment, making money, having health benefits, a purpose to my day, and being social." One man reported that he enjoyed "independence and control over my workplace and duties."

Participants who reported negative experiences said that working was sometimes difficult due to disability; that it sometimes felt demeaning to have to work; that their work environment was not enjoyable; and that they experienced ageism at work. For example, one woman wrote, "Because of my age, I was expected to remember 


\section{Author's Proof}

3 Harassment of Older Adults in the Workplace

way more than normal. Other people that did that job told me that it was a big guessing game." Another woman wrote, "Because I was older, the young girls thought I shouldn't be working, I should be at home waiting to die! They did everything they could to make my life there miserable and since the boss didn't try to stop it, I had to be quiet." One woman wrote,

After about age 60-65 I began to notice that people would sometimes ignore me as though I had become invisible. This is also evident in the way that co-workers, supervision, prospective employers and others discount or ignore my ideas, opinions, views and work experience that may be extremely relevant or helpful. One is also patronized or talked down to in many situations where younger people think I have no value. I am not able to find work at the level I had before this age.

\section{Conclusion}

In this section, I summarize findings from my study, provide a few caveats, and consider what the findings suggest in terms of how older workers' experiences might be improved. The most common harassment behaviors included having one's work contributions ignored; being left out of decisions that affect one's work; and being talked down to by coworkers and bosses. All of these behaviors share themes of isolation and personal devaluation. The lack of difference between men's and women's perceptions of their experiences suggests that gender may be a less salient aspect of workplace identity for older workers than it is for younger workers. When sharing their experiences in their own words, as was the case for those participants who chose to write additional comments on their surveys, many reported positive workplace experiences. Finally, and perhaps most importantly, those who did experience harassing behaviors tended not to talk with others about them.

What do these findings suggest about how we might improve workplace experiences for older people? Even though older workers tend not to discuss their harassment experiences with others, coworkers do appear to be a potential source of support. Educating employers about the importance of nurturing positive coworker relationships may be one way to enhance older workers' experiences. Findings from this study also demonstrated the need to speak with older workers directly - both to hear more about the sorts of experiences they reported in the survey and to hear from them directly about how to improve their experiences. Qualitative research is needed in order to learn more from older workers themselves.

The present findings suggest common patterns among older workers' experiences. However, the sample from which these findings were drawn was not representative of all older workers. The small sample size, combined with the limited pool from which the sample was drawn (only participants from one state who happened to 
405

406

407

408

409

410

411

412

413

414

415

416

417

418

419

420

421

422

423

424

425

426

427

428

429

430

431

432

433

434

435

436

437

438

439

440

441

442

443

444

445

446

447

448

449

450

451

452

453

454

455

456

\section{References}

Acker, J. (1990). Hierarchies, jobs, bodies: A theory of gendered organizations. Gender and Society, 4, 139-158.

Allen, K. R., \& Walker, A. J. (2006). Aging and gender in families: A very grand opening. In C. Toni \& K. F. Slevin (Eds.), Age matters: Realigning feminist thinking (pp. 155-174). New York: Routledge.

Altschuler, J. (2004). Beyond money and survival: The meaning of paid work among older women. International Journal of Aging \& Human Development, 58, 223-239.

American Association of Retired Persons (AARP). (2004). Baby boomers envision retirement II. Washington, DC: American Association of Retired Persons.

Appold, S. J. (2004). How much longer would men work if there were no employment dislocation? Estimates from cause-elimination work life tables. Social Science Research, 33, 660-680.

Barnett, R. C. (2005). Ageism and sexism in the workplace. Generations, 29, 25-30.

Bendick, M., Jr., Brown, L. E., \& Wall, K. (1999). No foot in the door: An experimental study of employment discrimination against older workers. Journal of Aging \& Social Policy, 10, 5-23.

Blackstone, A. (2003). Gender roles and society. In J. R. Miller, R. M. Lerner, \& L. B. Schiamberg (Eds.), Human ecology: An encyclopedia of children, families, communities, and environments. Santa Barbara: ABC-Clio.

Brooke, L., \& Taylor, P. (2005). Older workers and employment: Managing age relations. Ageing \& Society, 25, 415-429.

Bumiller, K. (1988). The civil rights society: The social construction of victims. Baltimore: Johns Hopkins University Press.

Calasanti, T. (1999). Impact of work on older adults (book review). Contemporary Sociology, 28, 178-179.

Calasanti, T. (2002). Work and retirement in the 21 st century: Integrating issues of diversity and globalization. Ageing International, 27, 3-20.

Calasanti, T., \& Slevin, K. F. (2001). Gender, social inequalities, and aging. Walnut Creek: AltaMira Press.

Calasanti, T., \& Slevin, K. F. (2006). Age matters: Realigning feminist thinking. New York: Routledge.

Cohen, L. E., \& Felson, M. (1979). Social change and crime rate trends: A routine activity approach. American Sociological Review, 44, 588-608.

Connolly, C. (2002). The voice of the petitioner: The experiences of Gay and Lesbian parents in successful second-parent adoption proceedings. Law and Society Review, 36, 325-346.

De Coster, S., Estes, S. B., \& Mueller, C. W. (1999). Routine activities and sexual harassment in the workplace. Work and Occupations, 26, 21-49.

Dennis, H., \& Thomas, K. (2007). Ageism in the workplace. Generations, 31, 84-89.

DeSouza, E., \& Solberg, J. (2004). Women's and men's reactions to man-to-man sexual harassment: Does the sexual orientation of the victim matter? Sex Roles: A Journal of Research, 50, 623-639.

Duncan, C. (2003). Assessing anti-ageism routes to older worker re-engagement. Work, Employment and Society, 17, 101-120.

Eichar, D. M., Norland, S., Brady, E. M., \& Fortinsky, R. H. (1991). The job satisfaction of older workers. Journal of Organizational Behavior, 12, 609-620.

Ekerdt, D. J., Kosloski, K., \& DeViney, S. (2000). The normative anticipation of retirement by older workers. Research on Aging, 22, 3-22.

Ewick, P., \& Silbey, S. S. (1998). The common place of law. Chicago: University of Chicago Press.

Ewick, P., \& Silbey, S. S. (2003). Narrating social structure: Stories of resistance to legal authority. The American Journal of Sociology, 108, 1328-1372.

Fairhurst, E. (2003). New identities of ageing: Perspectives on gender, age, and life after work. In A. Sara, D. Kate, \& G. Jay (Eds.), Gender and ageing: Changing roles and relationships (pp. 31-46). Maidenhead: Open University Press.

Felstiner, W. L. F., Abel, R. L., \& Sarat, A. (1980-81). The emergence and transformation of disputes: Naming, blaming, claiming.... Law and Society Review, 15, 631-654. 
3 Harassment of Older Adults in the Workplace

Fendrich, M., Woodword, P., \& Richman, J. A. (2002). The structure of harassment and abuse in the workplace: A factorial comparison of two measures. Violence and Victims, 17, 491-505.

Fineran, S. (2002). Adolescents at work: Gender issues and sexual harassment. Violence Against Women, 8, 953-967.

Fleury-Steiner, B. (2003). Before or against the law? Citizens' legal beliefs and experiences as death penalty jurors. Studies in Law, Politics, and Society, 27, 115-137.

Ford, C. A., \& Donis, F. J. (1996). The relationship between age and gender in workers' attitudes toward sexual harassment. The Journal of Psychology, 130, 627-633.

Giuffre, P. A., \& Williams, C. L. (1994). Boundary lines: Labeling sexual harassment in restaurants. Gender and Society, 8, 378-401.

Hess, B. (1990). Gender and aging: The demographic parameters. Generations, 14, 12-15.

Hirsch, B. T., Macpherson, D. A., \& Hardy, M. A. (2000). Occupational age structure and access for older workers. Industrial \& Labor Relations Review, 53, 410-418.

Hoffman, E. A. (2003). Legal consciousness and dispute resolution: Different disputing behavior at two similar Taxicab companies. Law \& Social Inquiry, 28, 691-716.

Hoffman, E. A. (2005). Dispute resolution in a worker cooperative: Formal procedures and procedural justice. Law and Society Review, 39, 51-82.

Hull, K. E. (2003). The cultural power of law and the cultural enactment of legality: The case of same-sex marriage. Law \& Social Inquiry, 28, 629-657.

Kanter, R. M. (1977). Men and women of the corporation. New York: Basic Books.

King, N. (2006). The lengthening list of oppressions: Age relations and the feminist study of inequality. In C. Toni \& K. F. Slevin (Eds.), Age matters: Realigning feminist thinking (pp. 47-74). New York: Routledge.

Knefel, A., Callender, M., \& Cryant, C. D. (2004). Workplace as combat zone: Reconceptualizing occupational and organizational violence. Deviant Behavior, 25, 579-601.

Koonin, M., \& Green, T. M. (2004). The emotionally abusive workplace. Journal of Emotional Abuse, 4, 71-79.

Kritzer, H. M., Vidmar, N., \& Bogart, W. A. (1991). To confront or not to confront: Measuring claiming rates in discrimination grievances. Law and Society Review, 25, 875-887.

Levy, J. A. (1988). Intersections of gender and aging. The Sociological Quarterly, 29, 479-486.

MacKinnon, C. (1979). Sexual harassment of working women: A case of sex discrimination. New Haven: Yale University Press.

Macnicol, J. (2006). Age discrimination: An historical and contemporary analysis. Cambridge: Cambridge University Press.

Marshall, N. L. (2001). Health and illness issues facing an aging workforce in the new millennium. Sociological Spectrum, 21, 431-439.

Marshall, A. M. (2005). Idle rights: Employees' rights consciousness and the construction of sexual harassment. Law and Society Review, 39, 83-123.

Marshall, A. M., \& Barclay, S. (2003). In their own words: How ordinary people construct the legal world. Law \& Social Inquiry, 28, 617-628.

Marshall, V. W., Heinz, W. R., Kruger, H., \& Verma, A. (Eds.). (2001). Restructuring work and the life course. Toronto: University of Toronto Press.

McLaughlin, H., Uggen, C., \& Blackstone, A. (2008). Social class differences in workplace harassment during the transition to adulthood. New Directions for Child and Adolescent Development, 119, 85-98.

McMullin, J. A. (2000). Diversity and the state of sociological theory. Gerontologist, 40, 517-530.

McMullin, J. A., \& Berger, E. D. (2006). Gendered ageism/age(ed) sexism: The case of unemployed older workers. In C. Toni \& K. F. Slevin (Eds.), Age matters: Realigning feminist thinking (pp. 201-223). New York: Routledge.

McMullin, J. A., \& Marshall, V. W. (2001). Ageism, age relations, and garment industry work in Montreal. Gerontologist, 41, 111-122.

Meadows, R., \& Davidson, K. (2006). Maintaining manliness in later life: Hegemonic masculinities and emphasized femininities. In C. Toni \& K. F. Slevin (Eds.), Age matters: Realigning feminist thinking (pp. 295-312). New York: Routledge. 
Merry, S. E. (1990). Getting justice and getting even: Legal consciousness among working class Americans. Chicago: University of Chicago Press.

Minichiello, V., Browne, J., \& Kendig, H. (2000). Perceptions and consequences of ageism: Views of older people. Ageing and Society, 20, 253-278.

Mor-Barak, M. E. (1995). The meaning of work for older adults seeking employment: The generativity factor. International Journal of Aging \& Human Development, 41, 325-344.

Mortimer, J. T. (2003). Working and growing up in America. Cambridge, MA: Harvard University Press.

Mueller, C. W., De Coster, S., \& Estes, S. B. (2001). Sexual harassment in the workplace: Unanticipated consequences of modern social control in organizations. Work and Occupations, 28, 411-446.

Nacelewicz, T. (2005). The graying of Maine. Maine Sunday Telegram, 117(40), 1-11.

National Institute for Occupational Safety and Health (NIOSH). (2004). Worker health chartbook. Cincinnati: NIOSH Publications Dissemination.

National Institute on Aging (NIA). (2007). Growing older in America: The health and retirement study. Bethesda: NIA.

Padavic, I., \& Orcutt, J. D. (1997). Perceptions of sexual harassment in the Florida legal system: A comparison of dominance and spillover explanations. Gender and Society, 11, 682-698.

Pitt-Catsouphes, M. (2005, September 6). Grant to study work options as boomers reach retirement. Press release. Chestnut Hill: Boston College.

Richman, K. D. (2001). In times of need: Abused women's sources of support and changes in legal consciousness. Studies in Law, Politics, and Society, 22, 171-194.

Richman, J. A., Rospenda, K. M., Nawyn, S. J., Flaherty, J. A., Fendrich, M., Drum, M. L., \& Johnson, T. P. (1999). Sexual harassment and generalized workplace abuse. American Journal of Public Health, 89, 358-363.

Rix, S. E. (2001). Restructuring work in an aging America: What role for public policy. In V. W. Marshall, W. R. Heinz, K. Helga, \& V. Amil (Eds.), Restructuring work and the life course (pp. 375-396). Toronto: University of Toronto Press.

Rix, S. E. (2005). Update on the older worker: 2004. Washington, DC: American Association of Retired Persons Public Policy Institute.

Rospenda, K. M. (2002). Workplace harassment, services utilization, and drinking outcomes. Journal of Occupational Health Psychology, 7, 141-155.

Rospenda, K. M., \& Richman, J. A. (2004). The factor structure of generalized workplace harassment. Violence and Victims, 19, 221-239.

Rospenda, K. M., Richman, J. A., \& Nawyn, S. J. (1998). Doing power: The confluence of gender, race, and class in Contrapower sexual harassment. Gender and Society, 12, 40-60.

Rospenda, K. M., Richman, J. A., Wislar, J. S., \& Flaherty, J. A. (2000). Chronicity of sexual harassment and generalized work-place abuse: Effects on drinking outcomes. Addiction, 95, $1805-1820$.

Schaie, K. W., \& Schooler, C. (Eds.). (1998). Impact of work on older adults. New York: Springer.

Siegenthaler, J. K., \& Brenner, A. M. (2000). Flexible work schedules, older workers, and retirement. Journal of Aging \& Social Policy, 12, 19-34.

Singh, G., \& Verma, A. (2003). Work history and later-life labor force participation: Evidence from a larger telecommunications firm. Industrial \& Labor Relations Review, 56, 699-715.

Smith, J. W., \& Calasanti, T. (2005). The influences of gender, race, and ethnicity on workplace experiences of institutional and social isolation: An exploratory study of university faculty. Sociological Spectrum, 25, 307-334.

Sterns, H. L., \& Miklos, S. M. (1995). The aging worker in a changing environment: Organizational and individual issues. Journal of Vocational Behavior, 47, 248-268.

Sterns, H. L., Barrett, G. V., Czaja, S. J., \& Barr, J. K. (1994). Issues in work and aging. Journal of Applied Gerontology, 13, 7-19.

Taylor, P., \& Walker, A. (1998). Employers and older workers: Attitudes and employment practices. Ageing \& Society, 18, 641-658.

Texeira, M. Y. (2002). 'Who protects and serves me?' A case study of sexual harassment of African American women in one U.S. law enforcement agency. Gender and Society, 16, 524-545. 


\section{Author's Proof}

3 Harassment of Older Adults in the Workplace

Tougas, F., Lagace, M., De La Sablonniere, R., \& Kocum, L. (2004). A new approach to the link between identity and relative deprivation in the perspective of ageism and retirement. International Journal of Aging \& Human Development, 59, 1-23.

Uggen, C., \& Blackstone, A. (2004). Sexual harassment as a gendered expression of power. American Sociological Review, 69, 64-92.

U.S. Bureau of the Census. (2006). Statistical abstract of the United States (125th ed.). Washington, DC: U.S. Government Printing Office.

U.S. Equal Employment Opportunity Commission (EEOC). (2006). Discrimination by type: Facts 572 and guidance. Retrieved January 30, 2006, from http://www.eeoc.gov/

Wakefield, S., \& Uggen, C. (2004). The declining significance of race in federal civil rights law: The social structure of employment discrimination claims. Sociological Inquiry, 74, 128-157. 575

Wayne, J. H. (2000). Disentangling the power bases of sexual harassment: Comparing gender, age and position power. Journal of Vocational Behavior, 57, 301-325.

Welsh, S. (1999). Gender and sexual harassment. Annual Review of Sociology, 25, 169-190.

Welsh, S., Carr, J., MacQuarrie, B., \& Huntley, A. (2006). 'I'm not thinking of it as sexual harassment': Understanding harassment across race and citizenship. Gender and Society, 20, 87-107. 


\section{Author's Proof}

\section{Author Queries}

Chapter No.: $3 \quad 0001653172$

\begin{tabular}{|l|l|l|}
\hline Queries & Details Required & Author's Response \\
\hline AU1 & Please check if section heading levels are set correctly. & \\
\hline
\end{tabular}

